\title{
The social appropriation of the Portuguese inner colonisation in Boalhosa
}

\author{
Marta Prista ${ }^{1,1}$ \\ ${ }^{1}$ Universidade Nova de Lisboa, Faculdade de Ciências Sociais e Humanas, CRIA/NOVA \\ FCSH, 1069-061 Lisbon, Portugal.
}

\begin{abstract}
Like other European regimes, the Portuguese Estado Novo (1933-1974) implemented an agricultural colonisation policy that, influenced by the ideals of modernism and neo-Physiocracy, aimed at economic development, social pacification and the fostering of national identities, resulting in the settlement and populating of modern rural landscapes. However, the Portuguese regime coped with an enduring financial crisis, and relied on an official nationalism built upon a conservative-traditional society under the union of God, fatherland, work and family. Unsurprisingly, Portuguese inner colonisation was comparatively small-scale, aimed at converting farmhands into rural homeowners, and its modernising experiments had limited impact on the landscape. However, landscape and place are not passive concepts. They concurrently build and are built by political and economic agencies, social negotiations, embodied experiences, plural meanings and affections. Looking into primary sources and the outcomes of a microethnography in Boalhosa, this paper intersects official-written history and emotional-sensory memory to illustrate consistencies and dissonances between political and social actors' representations of the Portuguese inner colonisation. Based on exploratory observations in Boalhosa, it argues that while the lack of political assertiveness may have curtailed the Portuguese project, it also favoured its social appropriation by local communities and economies within a contextualised historical spatial continuum.
\end{abstract}

\section{The context}

Throughout the $20^{\text {th }}$ century, most European totalitarian and authoritarian regimes implemented an agricultural inner colonisation policy that, influenced by modernist and neo-Physiocratic ideals, aimed at economic development, social pacification and the fostering of a national identity through the building and populating of modern rural landscapes. Modernism is here understood a priori of its cultural or artistic expressions. Rather, it is considered as an overall insurgency against the decadence of modernity, a stance precipitating a quest for modernist alternatives, including its palingenetic ultranationalist fascist forms [1]. The way in which modernism embraced the agrarian world

\footnotetext{
${ }^{1}$ Corresponding author: martaprista@gmail.com
} 
challenges the concept itself by reframing its biased urban positioning and allowing a more comprehensive study of its expressions and political variations [2]. Notably, the salvaging of $18^{\text {th }}$ century economic theories like Physiocracy, which advocated agrarian development through industrialisation and modernisation as the source of national wealth, provides a useful starting point. Within this frame, the MODSCAPES project ${ }^{2}$ (2016-2019) analyses the transnational phenomenon of agricultural and inner colonisation in $20^{\text {th }}$ century Europe to examine its physical and sociocultural impacts on modernist rural landscapes and shed light on the estrangements and rapprochements of different politics, programmes and physical remnants of the past.

In Portugal, inner colonisation fell within the action of the Junta de Colonização Interna $(\mathrm{JCl})$, which operated between 1936 and 1974 under the Ministry of Economy of the Portuguese Estado Novo dictatorship (1933-1974). Historical and documental inquiries evince parities with other European projects but Portuguese internal colonisation operated on a smaller scale and its agrarian reform sought the reinforcement of rural homeowners instead of the establishment of an industrial class. Portugal was a poor rural country living an enduring political and economic crisis since the $19^{\text {th }}$ century [3]. Its dictatorship relied on a conservative society that, differently from the revolutionary populist forces that drove other European fascist movements, sought to restore a traditional order and hierarchy [4], and the regime rewarded elites for their loyalty, regardless of their Catholic, monarchic or liberal standings [5]. This helps explain the political and ideological pluralism that characterised the Portuguese agrarian reform debates since the $19^{\text {th }}$ century. It also accounts for the constraints of the JCl's technical-scientific programme and the limited impact of the colonisation project on the Portuguese rural landscape. While the $\mathrm{JCl}$ declared the rationalisation of natural and human resources through land restructuring and agricultural modernisation, it had to adjust to economic shortages, political difficulties, nationalist social engineering policies, and the agency of the Portuguese elites [6].

\section{The approach}

This paper focuses on the extent to which the ambiguities and negotiations that involved Portuguese inner colonisation were manifest in specific projects, and the ways in which they are represented today. Considering that landscapes, like places, are not passive concepts, but concurrently build and are built by political and economic agencies, social negotiations, embodied experiences, and plural meanings and affections [7], this paper proposes an exploratory analysis of the dialectics between the social production of space (economic, ideological and technological factors) and the social construction of space (sensorial, symbolic and affective experience) [8]. Its approach falls within an anthropological conceptual and methodological framework that is grounded in ethnographic and comparative inquiry as a mode of critically understanding social and cultural dynamics. Yet, accommodating the constraints of time and scope of the transdisciplinary and transnational MODSCAPES project, this paper leads with representation as a social and cultural phenomenon, but makes use of microethnography ${ }^{3}$ as a way of addressing specific representations which are socially constructed within one particular setting of a cultural ethos which, if attended to in its entirety, would demand for a more holistic approach [9].

\footnotetext{
${ }^{2}$ https://modscapes.eu

3 Also known as focused ethnography, specific ethnography, or rapid ethnography.
} 
Building upon the micro-ethnography carried out in the colony of Boalhosa, this paper aims to discuss the dialectics between official history as recorded in the archives, its academic reasoning, and the memory of local inhabitants, in what concerns the representation of processes of colonisation and modernism. It intersects primary and secondary sources with data collected at a local workshop, informal conversations and interviews with settlers, as well as local observation ${ }^{4}$. Ultimately, the paper intends to evaluate whether the ambiguities and negotiations between different representations fostered a sense of place and/or situated the colony in a realm of heritage imagination today. However, because memory and history are dynamic and contextual, and acts of recognition alter the past in each present moment [10], there is no ambition in setting a truth, only an account of the multivocal ways in which modernisation and colonisation in Boalhosa are seen today. A denser analysis is precluded due to space constrains and the multifaceted and multi-sited nature of the MODSCAPES project. Still, selected results and reasoning illustrate the argument and provide insights for future comparative analysis.

\section{Representations of modernisation}

Boalhosa was the last colony to be built. Although planning started in 1946, the settlers only arrived at the colony on the eve of 1960 . By then, the European post-war political, economic and social order had restrained the Portuguese dictatorship's more fascistic expressions; the country was pervaded by modern lifestyles; and the $\mathrm{JCl}$ had adjusted its project to the context and the setbacks identified in previous initiatives [11]. This influenced the architectural, urban and agricultural projects of Boalhosa in material and social ways that shaped how its inhabitants now reimagine the local processes of modernisation and colonisation as an event understood in deep continuity with a traditional lifestyle, rather than the localized expression of a national policy and programme that aimed at the establishment and imposition of a modernist rule over a territory and its people (i.e. colonisation).

Modernisation, for instance, is unanimously acknowledged in functional terms, but not in the rational and aesthetic values of its architectural features. Depicting their homes, settlers repeat they "had a whole new kind of housing condition" and cite the running water, inside toilet, separate rooms for parents and female and male children, inside storerooms, fireplace, and solid construction materials. But the modernist rationalisation of solar and wind exposure, topography and volumetric efficiency, use of regional techniques and materials [12], are absent from the discourse. Even the unitary semi-detached house that in the literature is emphasized as an expression of modernist inspiration in vernacular architecture and its rationalisation of space [11], is considered to be simply the result of the cost-saving measures of a parsimonious $\mathrm{JCl}$. Quoting the additional area of $100 \mathrm{~m}^{2}$ in the dwellings of the neighbouring Barroso colony and complaining about the unsanitary nature of having feeding troughs indoors, the Boalhosa settlers conclude that they have "the worst houses". Overall, not only are they

\footnotetext{
${ }^{4}$ The data consist in documental and bibliographic research in national and informal archives, exploratory fieldtrips to several colonies during 2017, local fieldwork in Boalhosa during which a workshop and an exhibition occurred (18-21 September 2017), several informal conversations in different colonies, and semi-structured in-depth interviews with ten current settlers of Boalhosa. This paper also benefitted from the input of other studies developed by members of the Portuguese MODSCAPES team regarding documental research in regional and national archives, photographic surveys and three interviews with past and present local agents in Boalhosa.
} 
unaware of the concept of modernism, as their outlook on the houses of the colony reveals a subtext of the traditional "farmer house" which, in turn, guides their social aspirations.

Urban features support other conflicting readings. Portuguese colonisation never settled on one model. Either due to its lateness or its peripheral location, Boalhosa exhibits a nucleated pattern that seems to have been borrowed from the successes of similar foreign programmes in reinforcing local communities and enforcing social control. While this may be so, settlers regard their settlement as a token of the modern world. Aligned roadways, direct access to dwelling, and closeness of plots and school, support statements like "Here we had amenities because they were all nearby". One settler even quoted the resemblances with some French villages as an argument in favour of the settlement's modernity. And yet, conversely, settlers also complain that "back then, we had nothing", describing the lack of public equipment, electricity, sewers, telephone or public pavement. Again, they place functionalism at the core of the local modernisation process, but its traits seem to be appreciated in direct proportion to its capacity to improve a traditional rural lifestyle.

Contrasting representations of Boalhosa as both an expression of modernity and a spatialization of traditional rural lifestyles also envelop the agrarian project. Official documents reveal an attempt to rationalise cultures through technical analysis and experiments [13, 14]. However, despite occasional comprehension, the settlers primarily envision the modernising enterprise in its mystifying alien machinery: "Good heavens! I'd never seen such a thing! When we went up, we'd see the tires glinting on the road! It was a delightful thing to see." The tractor signified modernity. Settlers know that Boalhosa was a government-run agricultural colony and that the local foreman was a technician assigned by the State. But most are unaware of the global $\mathrm{JCl}$ project, let alone of its European equivalents. As such, the national enterprise is largely represented as a localized phenomenon. In addition, rural life is perceived traditionally in the local accounts of family lifestyles. Settlers recall "getting together and collecting potatoes for one another" and long for the times of "corn husking, when everyone went to [work in] that same field...". Such memories of solidarity and reciprocity thus mirror an "agrarian communitarianism" that, far from modern social and economic structures, was founded on kinship as the basis for agrarian production and consumption, and translated the traditional horizontal social organisation of Northern Portuguese rurality [15].

\section{Representations of colonisation}

The case study of Boalhosa demonstrates how the modernisation of material, social and economic structures in the Portuguese inner colonies must be understood with reference to its temporal and spatial particularities and, in particular, its intertwining with traditional rural lifestyles. An examination of the social engineering project of the $\mathrm{JCl}$ and the settlers' descriptions of the colonisation process further emphasizes the malleability of the State's quest to discipline rural populations within the modernist colonial project. Perhaps surprisingly, its lack of assertiveness appears however to have contributed to the development of feelings and practices of social inclusion and exclusion that became the grounds for a sense of belonging, community and place [7].

The selection of settlers is a good case in point. Unanimously, reports and legislation blame the failure of the first colony (Milagres, 1926) on its poor selection of applicants and use this experience to justify a revision of the necessary criteria for selection. Along with the physical and moral fitness for rural work, priorities regarding age, origin, 
experience and nuclear family were tweaked in a bid to widen the geographic scope from which applicants could be drawn as well as the work capacity of settler families [16]. Notwithstanding, in Boalhosa, people remember the existence of unmarried settlers, and of technicians directly inviting suitable farmworkers to become settlers. This may have been a strategy to overcome the fact that of 30 dwellings only 13 were initially attributed and ten effectively inhabited [17]. But the expulsion of settlers who had drifted to commercial activities $[18,19]$ suggests yet another factor.

Colony dwellings were conceived as technical-economic units to ensure the selfsufficiency of "healthy, strong, and a guarantor of nationality" settlers [20]. This echoed the settlers' own motivations to apply: their aspirations of owning their own homes and working for their own profit. But it also reveals the Estado Novo's nationalistic construction of the Portuguese New Man as a middle-aged breadwinner, a man who loved the land and was able to put into practice the regime's doctrine of God, fatherland, family, and work [21]. Consistently, legislation enforced the property's indivisibility and inalienability [22]; official propaganda instilled the image of domestic architecture as a sign of national prosperity [23]; and the media extolled private property as the triumph of the Portuguese New Man [24]. In other words, the political-ideological agenda of the State took precedence over the technical-scientific project of the $\mathrm{JCI}$.

The malleability of the process of colonisation in Boalhosa extended to the activities of the technicians who provided technical and moral assistance [25]. Their mission was to transform rural workers into small rural farmers thus putting into practice the idea that both economy and morality were rooted in the land. However, in their reports, they account for difficulties such as a discomfort in providing advice to women on family, hygiene or food, and the strategies they employed to urge more collaborative attitudes among the settlers [26]. These included building up trust and friendship by conducting themselves as though their presence was at the service of the settlers. However, according to the settlers themselves, technicians never entered their houses nor controlled family business. The idea of friendship is based precisely on mutual respect and understanding. Settlers remember being granted authorisation to farm unused land and complete primary education during work hours, and recall how technicians turned a blind eye to certain forbidden practices such as daily wage labour or emigration. Perhaps the social control of Boalhosa's settlers was loosened to ensure the continuity of the colony, given the technicians' remarks on the uprooting effect that migration was causing. But whatever the reasons, such strategies facilitated an affective bond between the settlers and the colonial structure.

These bonds were further reinforced by both the settlers' life stories and the strategies of the $\mathrm{JCl}$ in forging a sense of community inter and intra colonies. On the one hand, as the settlers state, "Here, almost everyone is family". Indeed, six houses were assigned to three sets of cousins and throughout the years settlers married within (and outside of) the colony. Today, all the 14 houses occupied are kinship-related at least to one other. One particular household is notably related to seven others. On the other hand, the $\mathrm{JCl}$ endeavoured to instil a collective representation of inner colonisation among the settlers by promoting professional training in agrarian-related issues [27], occasionally organising summer colonies for the settlers' children [28], or even hiring them as part of the working population from as young as ten years of age [13]. The settlers' representation of the colonisation programme is indeed marked by their personal experiences and recollections of marriages between settlers, settlersturned-technicians or their direct employment in the $\mathrm{JCl}$ as drivers or machine operators. 
The final initiative of the $\mathrm{JCl}$ resulted from its 1962 reorganisation and its regulation of agricultural cooperatives and funding [29]. In 1971, settlers became equal partners in the Boalhosa Agriculture Society, and houses and plots were redistributed among the ten remaining families. This initiative transformed the $\mathrm{JCl}$ colony into its own locus of economic investment and communal life.

\section{A sense of place}

The colony of Boalhosa was extinguished in 1988 [30] with its settlers striving and eventually succeeding in acquiring legal rights over their homes and plots. The Boalhosa Agriculture Society was dismantled in 1998 and most settlers have poor memories of its accomplishments and ending, mostly related to economic difficulty and generational conflicts. Such memories denote both the loss of a sense of community and, paradoxically, a continuity of affective investment in a sense of place.

Within this constellation of feelings, generational differences are manifest. On the one hand, there is an emotional disinvestment of settlers who saw their collective project fail and, in contrast, a "natural" affection of those born in the colony: "it is same as any other place," said a settler; "for me, it is special", answered his daughter. On the other hand, the terms used by settlers to differentiate the original settlers (the provisional) and the settlers-turned-owners (the definitive) are enlightening in their persistent anchoring to place. The emotionally charged memory of one event in the mid-1970s is particularly significant. In the post-revolutionary ambiance, a border parish claimed rights over part of Boalhosa's land [31]. All generations of settlers united around the common threat, arguing, "in the tough days, no one wanted to abandon what they had to come here" just "because they did not want to work" and now "they say we stole their lands". The dispute was settled in court, but more importantly, nowadays, it testifies to the prejudices between settler and non-settler neighbours and thus spatialise Boalhosa's imagined border, demarcating the boundaries of inclusion and exclusion that are inherent to any sense of place, community and belonging.

However, further research is needed to ascertain whether these representations and feelings translate into an understanding of the modern colony as a form of cultural heritage. Heritage is a cultural practice that constructs a set of values and meanings, but it is also a social practice operating in time through acts of remembering and engagement of which discourse is a significant expression [32]. Indeed, all settlers activate the rhetoric of loss that undergirds the heritage processes in discourses that place the origins of social disaggregation in new local economies and migration flows. In spite of this, the sentiment that "now, it's every man for himself" and the increasing dissatisfaction stemming from the growing threats to farmland on account of current efforts in wildlife conservation, unveils a nostalgic longing for the traditional agrarian communitarianism more than a representation of the modernist rural landscape as cultural heritage.

Notwithstanding, the alteration of the past is also an expression of its comprehension and its relation to the present [10]. It is true that recent transformations of the dwellings display an emblematisation of the rural past, along with more functional updates. A common trait is the conversion of the manger into a second larger kitchen to gather the whole family and reproduce traditional forms of commensality and socialisation. Also illustrative is the maintenance of the lifting hook or the stone facings for the sake of memory. However, in some houses, the remodelling introduced contemporary design features such as new coatings, kitchen furniture and new stairs. These were deliberately thought to give visibility to original features such as the wood stove, the 
chimney, the stone walls, or the view to the yard and the open-space living-roomcirculations. So, these elements remit to a traditional rurality just as much as they invoke its modernist interpretation...

\section{Final remarks}

These exploratory observations on the memories and perceptions of Boalhosa's colonisation and modernisation are far from exhaustive. Nevertheless, they disclose how the Portuguese project's lack of political assertiveness and coherence did not preclude the local processes of social cohesion and the establishment of a rural economy. The main hypothesis here is that settlers socially appropriated modernisation and colonisation projects by collectively making these practices and meanings their own through interactive and reinterpretative processes. Such processes operate on a contextualised historical and spatial continuum, making generalisations within the Portuguese programme problematic. For instance, loosened social control in Boalhosa is a plausible assertion, but an analogous analysis in Pegões would reveal records of its fascistic sports demonstrations, social and medical assistance, or the availability of courses on domestic economy and women's affairs [33].

Still, future comparative micro-ethnographies can provide valuable insights to better understand the nuances and the challenges of the colonisation policies and projects, their modernising and modernist subtexts, and today's representations and appropriations of the processes of modernisation and colonisation. Such studies can help to avoid the risks of essentialising concepts and practices, and enhance the dialogue with other theoretical debates. For instance, the case of Boalhosa suggests that the intervention of the $\mathrm{JCl}$ did not intend to abolish a traditional peasant lifestyle. These observations have implications in the framing of agrarian policies within the political realm, notably in the European era of fascisms, but also in the conceptions of modernism and modernisation within both intellectual and social forums. To these debates also the multi-sited approach of MODSCAPES can contribute as it spatializes intertwined discourses and practices at the transnational, national and local scales.

\section{Acknowledgements}

This work was conducted under the project MODSCAPES - Modernist Reinventions of the Rural Landscape (HERA.15.097), a collaborative research project funded under the HERA Humanities in the European Research Area 3rd Joint Research Program dedicated to "Uses of the Past" (2016-2019). This project has received funding from the European Union's Horizon 2020 research and innovation program under grant agreement $n^{\circ} 649307$.

\section{Short resume}

Marta Lalanda Prista. PhD (2011) and MSc (2005) in Anthropology from FCSH / Universidade Nova de Lisboa, architect graduated at the Faculdade de Arquitectura de Lisboa (2000). She is currently a full researcher at CRIA (Centro em Rede de Investigação em Antropologia) and a member of CRIA's Executive Board. Marta Prista's research intertwines anthropology, history and architecture with focus on issues like identity, memory, uses of culture, consumption and social distinction. In this scope, she has published and participated in research projects, advanced training courses and science dissemination actions in the fields of heritage and tourism. Currently, she is a member of MODSCAPES team. 


\section{References}

1. GRIFFIN, R. 2007. Modernism and Fascism: The Sense of a Beginning under Mussolini and Hitler, Hampshire, Palgrave Macmillan. DOI: https://doi.org/10.1057/9780230596122

2. FERNÁNDEZ-PRIETO, L.; PAN-MONTOJO, J.; CABO, M. (eds.) 2014. Agriculture in the Age of Fascism: Authoritarian Technocracy and Rural Modernization, 1922-1945, Turnhout, Brepols.

DOI: https://doi.org/10.1484/M.RURHE-EB.5.106196

3. LAINS, P.; SILVA, A. (eds.) 2005. História Económica de Portugal 1700-2000 [Economic History of Portugal 1700-2000], Lisbon, ICS.

4. GRIFFIN, R. 2008. A Fascist Century, Hampshire, Palgrave Macmillan. DOI: https://doi.org/10.1057/9780230594135

5. FERREIRA, N.; CARVALHO, R.; PINTO, A. 2009. "The 'Empire of the Professor': Salazar's Ministerial Elite, 1932-44", in A. Costa Pinto (ed.), Ruling Elites and Decision-Making in Fascist-Era Dictatorships, Boulder, Social Science Monographs: 119-136.

6. SILVA, E. 2011. A propriedade e os seus sujeitos: colonização interna e colónias agrícolas durante o Estado Novo [Property and its subjects: inner colonisation and agricultural colonies during the New State], (Master Thesis), Lisbon, NOVA FCSH.

7. FELD, S; BASSO, K. (eds.) 1996. Senses of Place, Santa Fé, School of American Research Press.

8. LOW, S. 1996. "Spatializing Culture: The Social Production and Social Construction of Public Space in Costa Rica", American Ethnologist, vol. 23, $\mathrm{n}^{\circ} 4: 861-879$.

9. WOLCOTT, H. 1990. "Making a study 'more ethnographic' ", Journal of Contemporary Ethnography, vol. 19, $\mathrm{n}^{\circ}$ 1: 44-72.

10. LOWENTHAL, D. 1985. The Past is a Foreign Country, Cambridge, Cambridge University Press.

11. GUERREIRO, F. 2015. Colónias Agrícolas Portuguesas construídas pela Junta de Colonização Interna entre 1936 e 1960 [Portuguese Agricultural Colonies built by the Inner Colonisation Board between 1936 and 1960], (PhD dissertation), Oporto, Faculdade de Arquitetura da Universidade do Porto.

12. JCI, 1954. Boalhosa: Projecto da casa-tipo [Boalhosa: Project of model-house], Lisbon, Ministry of Economy.

13. JCI, 1946. Núcleo da Boalhosa: Projecto de colonização [Boalhosa Nucleus: Colonisation Project], Lisbon, Ministry of Economy.

14. JCI, 1964. Gestão e contabilidade agrícolas: Exercício 1962/63 [Agricultural management and accounting: Exercise 1962/63], Lisbon, Ministry of Economy.

15. POLONAH, L. 1985. "O colectivismo agrário no norte de Portugal" [Agrarian collectivism in Northern Portugal], Antropologia Portuguesa, n 3: 61-68.

16. Decree-Law n 44:720, Diário do Governo, 28 November 1962.

17. MARQUES, A. 2014. "Convívio social e religioso entre famílias de agricultores integrantes da Junta de Colonização Interna: o caso das colónias dos Milagres 
e da Boalhosa" [Social and religious socialisation among families of farmers of the Inner Colonisation Board: the case of Milagres and Boalhosa colonies], in M. Araújo, A. Esteve, R. Silva, et al. (eds.), Socialibilidades na Vida e na Morte (Séculos XVI-XX), Braga, CITMEM: 175-184.

18. JCI [1961]. Colónia Agrícola da Boalhosa: Relatório de 1960 [Agricultural Colony of Boalhosa: 1960 Report], Lisbon, Ministry of Economy.

19. JCl [1962]. Colónia Agrícola da Boalhosa: Relatório de 1961 [Agricultural Colony of Boalhosa: 1961 Report], Lisbon, Ministry of Economy.

20. SNI, n.d. Colonização Interna [Inner Colonisation], Lisbon, Edições SNI.

21. CARVALHO, R; PINTO, A. 2017. "The 'Everyman' of the Portuguese New State during the Fascist Era", in J. Dagnino, M. Feldman, P. Stocker (ed.), The "New Man" in Radical Right Ideology and Practice, 1919-45, London, Bloomsbury: 131-147.

22. Decree-Law $n^{\circ}$ 36:709, Diário do Governo, 5 January 1948.

23. MACEDO, M. 1942. A Casa Rural: A Habitação [The Rural House: The Dwelling], Lisbon, Ministry of Economy.

24. Notícias de Coura (1957), series II, n 39, 15 November: 1.

25. Decree n० 35:994, Diário de Governo, 23 November 1946.

26. JCI, 1960. Gestão e contabilidade agrícolas: Exercício de 1958/59: Relatório II [Agricultural management and accounting: Exercise 1958/59: Report II], Lisbon, Ministry of Economy.

27. JCl [1964]. I Curso de Monitores de Mecanização Agrícola: Relatório. 1963/1964 [I Course of Agricultural Mechanisation Monitors: Report 1963/1964], Lisbon, Ministry of Economy.

28. Notícias de Coura (1960), series VIII, 27 August.

29. Decree-Law no 44:720, Diário do Governo, 28 November 1962.

30. Decree-Law n 482/88, Diário da República, 26 December 1988.

31. Notícias de Coura (1978), 20 December.

32. SMITH, L. 2006. The Uses of Heritage, London, Routledge.

33. $\mathrm{JCl}$ [n.d.]. Actividades da Junta de Colonização Interna: Documentação Fotográfica [Inner Colonisation Board Activities: Photographic Documentation], Lisbon, Ministry of Economy. 